\title{
KONFLIKTY EKOLOGICZNE A DZIAŁANIA ZBIOROWE W ZAKRESIE UŻYTKOWANIA I OCHRONY ŚRODOWISKA PRZYRODNICZEGO
}

\section{WSTĘP}

Zachodzące procesy globalizacyjne i integracyjne we współczesnym świecie sprawiają, że nasz świat staje się coraz mniejszy, zarówno w odniesieniu do relacji ekonomicznych i społecznych, jak również z perspektywy użytkowania i ochrony środowiska przyrodniczego. Odzwierciedleniem tego są, przede wszystkim, następujące zjawiska: po pierwsze, mamy do czynienia ze wzrastającą współzależnością gospodarczą, a po drugie, obok umiędzynarodowienia się procesów gospodarczych, a częściowo także w wyniku nich, również problemy środowiska przyrodniczego nabierają coraz bardziej międzynarodowego charakteru. Oczywiście, nie wszystkie problemy ekonomiczne, społeczne oraz wynikające z ochrony i użytkowania środowiska przyrodniczego powinny być rozwiązywane w skali międzynarodowej. Największą efektywność osiągniemy, jeżeli strategię rozwiązywania dostosujemy do skali przestrzennej ich występowania.

Problematyką ekologiczną zaczęto się poważnie interesować od połowy $\mathrm{XX}$ wieku. Wtedy to przenikające do świadomości użytkowników środowiska przyrodniczego i decydentów problemy wynikające $z$ degradacji środowiska oraz związane z tym zagrożenia dla jakości życia ludzi i możliwości wzrostu dobrobytu spowodowały zmianę sposobu myślenia o procesach i zjawiskach występujących w relacjach środowiska przyrodniczego i systemu gospodarczo-społecznego. Do polityki i praktyki gospodarczej zaczęły przenikać idee trwałego, zrównoważonego rozwoju, a z tym wiązało się tworzenie nowych instytucji formalnych w zakresie użytkowania i ochrony zasobów środowiska przyrodniczego. W Raporcie Brundtland napisano, że zrównoważony, trwały rozwój (sustainable development) 
jest rozwojem zaspokajającym bieżące potrzeby, przy jednoczesnym uniemożliwieniu zaspokajania ich w przyszłości ${ }^{1}$.

Zrównoważony rozwój (ekorozwój) oznacza taki rozwój, w którym tworzone są komplementarnie i równorzędnie łady: ekonomiczny, społeczny, ekologiczny, przestrzenny i instytucjonalny. Osiągnięcie tych celów wymaga współpracy pomiędzy ludźmi, grupami społecznymi, podmiotami gospodarczymi, organami władzy, ale także może wywoływać konflikty.

Konflikty ekologiczne oznaczają powstanie antagonistycznych stosunków w następstwie zaistnienia realnej lub potencjalnej sprzeczności interesów i priorytetów dotyczących kształtowania, korzystania i ochrony środowiska przyrodniczego. Przesłanką tych konfliktów są nieograniczone oczekiwania społeczeństw $\mathrm{w}$ odniesieniu do konsumpcji dóbr materialnych i niematerialnych (w tym pozaprodukcyjnych dóbr środowiskowych), połączone z rzadkością zasobów do ich zaspokojenia. W ich następstwie może dochodzić do współpracy przybierającej formę działan zbiorowych, to jest tworzenia grup interesu stanowiących koalicję osób, działających w celu osiągnięcia dobra wspólnego.

Celem artykułu jest przedstawienie działań zbiorowych w relacjach człowiek-środowisko przyrodnicze-gospodarka na tle problemów związanych z realizacją koncepcji ekorozwoju, który wprowadzając zasady i ograniczenia w gospodarczym użytkowaniu środowiska przyrodniczego oraz nakazując jego ochronę, wpisuje się w przyczyny konfliktów wynikających ze sprzecznych oczekiwań i interesów poszczególnych podmiotów gospodarczych, grup społecznych, społeczności lokalnych, rządów i obywateli niektórych krajów, mieszkańców różnych regionów świata.

Rozważania nawiązują do dorobku nowej ekonomii instytucjonalnej, a szczególnie do teorii działań zbiorowych i grup interesu oraz do dorobku ekonomii ekologicznej.

\section{MOŻLIWOŚĆ WYSTĄPIENIA KONFLIKTÓW W REALIZACJIZASAD EKOROZWOJU}

Określenie obszarów potencjalnych konfliktów ekologicznych wymaga spojrzenia na środowisko przyrodnicze $\mathrm{z}$ perspektywy jego użytkowników, w tym podmiotów gospodarczych, dokonujących różnorodnych wyborów dla realizacji określo-

\footnotetext{
1 G. H. Brundtland, Our Common Future, Report of the World Commission on Environment and Development, Oxford University Press, Oxford 1987. Używany w Polsce termin „ekorozwój” jest synonimem pojęć „zrównoważony rozwój” lub „trwały rozwój”.
} 
nych celów gospodarczych i nie tylko. Istotne dla nich funkcje środowiska przyrodniczego można sprowadzić do trzech sytuacji²:

1. Środowisko jako dostawca czynników wytwórczych - dostarcza czynników produkcji, zarówno tych, które samo wytworzyło jako dobra pierwotne (np. dóbr mineralnych, ryb, gleb) i które zostały pobrane ze środowiska, jak i tych, które powstały w wyniku świadomej działalności produkcyjnej człowieka $z$ wykorzystaniem zasobów i sił przyrody (np. rośliny uprawne).

2. Środowisko jako usługa - umożliwia transfer kosztów, to znaczy jest medium, które odbiera zanieczyszczenia oddziałujące następnie na odbiorców kosztów zewnętrznych, a także udostępnia zdolność asymilacyjną do przyjęcia tych składników działalności gospodarczej i innej, które powstają jako dobra niechciane, lub wręcz przeszkadzające tworzeniu i wykorzystaniu dóbr pożądanych.

3. Środowisko jako stan - tworzy warunki do wszelkiej działalności ludzi (w tym gospodarczej), to znaczy, że z punktu widzenia ludzi podejmujących działania służące zaspokojeniu ich potrzeb, nadaje się do umieszczenia działalności mającej przynosić poprawę dobrobytu (np. klimat, dostępność wód, ukształtowanie powierzchni).

Funkcje te odpowiadają świadomym zazwyczaj, a po części nieuświadomionym przez poszczególnych producentów i konsumentów oczekiwaniom wobec środowiska przyrodniczego. Nie zawsze spełnianie oczekiwań indywidualnych oznacza osiągnięcie ogólnospołecznych celów zrównoważonego rozwoju.

Według rozbudowanej definicji D. Pearce'a i R. Turnera zrównoważony, trwały rozwój (sustainable development) polega na „maksymalizacji korzyści netto z rozwoju ekonomicznego, chroniąc jednocześnie oraz zapewniając odtwarzanie się użyteczności i jakości zasobów przyrodniczych (naturalnych) w okresie długim. Rozwój gospodarczy musi wówczas oznaczać nie tylko wzrost dochodów per capita, ale także poprawę innych elementów dobrobytu społecznego. Musi on obejmować również niezbędne zmiany strukturalne w gospodarce, jak i całym społeczeństwie"

Tak zdefiniowana zrównoważoność zawiera ważne dla współczesnego świata wartości ${ }^{4}$ :

2 A. Graczyk, Ekologiczne koszty zewnętrzne. Identyfikacja, szacowanie, internalizacja, Wyd. Ekonomia i Środowisko, Białystok 2005, s. 22-23.

3 D. Pearce, R. K. Turner, Economics of Natural Resources and the Environment, New York 1990, podaję za: A. Woś, Rozwoój zrównoważony, „Zagadnienia Gospodarki Rolnej” 1992, nr 1-3,

${ }_{4}$ A. Pawłowski, L. Pawłowski, Zrównoważony rozwój we wspótczesnej cy wilizacji. Częśś 1: Środowisko a zrównoważony rozwój, „Problemy Ekorozwoju - Problems of sustainable development” 2008, vol. 3, no. 1, s. 53-65. 
- społeczne, odnoszące się do potrzeby sprawiedliwości wewnątrz- i międzygeneracyjnej, osiąganej przez zapewnienie zaspokojenia ludzkich potrzeb biologicznych, psychicznych i socjalnych;

- ekologiczne, nakazujące ochronę wszystkich elementów środowiska i zasobów przyrodniczych;

- ekonomiczne, zmierzające do poszerzenia analizy efektywności działalności gospodarczej (prowadzonej wcześniej z punktu widzenia maksymalizacji zysku) o zintegrowaną analizę ekoefektywności, w której uwzględnia się nie tylko zysk, ale także konsekwencje oddziaływania na środowisko procesów produkcyjnych i konsumpcyjnych (m.in. zanieczyszczanie wody, powietrza, gleby), pociągających za sobą coraz szybsze zużywanie zasobów przyrodniczych (poczynając od ich wydobycia, poprzez transport, przetwarzanie, dystrybucję, sprzedaż towarów, użytkowanie, na utylizacji i recyklingu kończąc).

Zrównoważony rozwój wymaga jednoczesnego osiągnięcia następujących celów: ekonomicznego, społecznego, ekologicznego, przestrzennego i instytucjonalnego. Osiągnięcie poszczególnych celów może wywoływać konflikty. Mogą pojawić się sprzeczności między interesami i oczekiwaniami dotyczącymi jakości środowiska przyrodniczego a realizacją rozwoju i wzrostu gospodarczego (np. wzrost realnego dochodu per capita w obecnym czasie a zagwarantowanie dostępu do zasobów, usług i stanów środowiska przyrodniczego poprzez aktualnie żyjące i przyszłe generacje), konflikty mogą dotyczyć realizacji sprawiedliwości wewnątrzpokoleniowej i międzypokoleniowej czy też równości szans w rozwoju cywilizacyjnym poszczególnych społeczeństw, krajów i regionów, a wreszcie lokalizacji inwestycji niechcianych czy „brudnych technologii”.

Konflikty ekologiczne są jednym $\mathrm{z}$ rodzajów konfliktów społecznych, wyodrębnionych ze względu na przedmiot sprzeczności międzyludzkiej, którym jest, ogólnie mówiąc, stan środowiska, w którym egzystuje człowiek. Myślenie w kategoriach ekologicznych nadal napotyka bariery w postaci dotychczasowych struktur wytwarzania i konsumowania dóbr oraz związanych $z$ nimi tendencji rozwojowych, co wytwarza ową sprzeczną strukturę interesów.

Analiza przyczyn konfliktów powstających na tle realizacji zasad ekorozwoju pozwala na stwierdzenie, że przyczynami tych konfliktów mogą byćs:

- niewystarczające informacje lub ich brak,

- rzeczywiste sprzeczności interesów lub postrzeganie ich jako sprzeczne (potencjalna sprzeczność interesów),

5 J. D. Priscoli, Public Involvement, Conflict Management, Means to EQ and Social Objectives, "Journal of Water Resources Planning and Management"1989, vol. 115, no. 1. 
- różnice w wyznawanych wartościach,

- konfliktogenne stosunki między podmiotami - uczestnikami konfliktu.

Brak lub ograniczony dostęp do odpowiednich informacji, asymetria informacyjna, nierzetelność danych oznaczają nieprzejrzyste warunki podejmowania decyzji. Może to sprzyjać powstawaniu sytuacji konfliktowych wynikających $\mathrm{z}$ domniemania o ukrytych celach podejmowanych działań, które, w domyśle, są sprzeczne $z$ interesami innych użytkowników środowiska przyrodniczego.

Przyczyną konfliktów mogą być różnice w wyznawanych systemach wartości, normach, zasadach i regułach postępowania akceptowanych przez poszczególne osoby i grupy społeczne. Wyznaczają one ich stosunek do środowiska przyrodniczego oraz ich oczekiwania i sposoby postępowania w relacjach człowiek-środowisko przyrodnicze-gospodarka. Szczególne znaczenie mogą mieć konflikty międzygeneracyjne dotyczące stopnia i zakresu eksploatacji bogactw naturalnych czy kształtowania przestrzeni. Uwzględniając międzypokoleniową sprawiedliwość ekologiczną, można dodać jeszcze jedną przyczynę konfliktów, a mianowicie sprzeczność pomiędzy osiąganiem celów krótkookresowych i długookresowych. Dążenie do krótkookresowego maksymalizowania funkcji celu (np. maksymalizacja dobrobytu w okresie krótkim) może ograniczać (lub wręcz uniemożliwiać) osiągnięcie określonego celu w przyszłości (np. maksymalizację dobrobytu przez przyszłe pokolenia).

Konfliktogenne mogą być stosunki między poszczególnymi użytkownikami środowiska przyrodniczego oparte na zrodzonej wcześniej niechęci lub wrogości. Wówczas istotną rolę mogą odgrywać emocje, a konieczność spotkania się (uczestniczenia) przy danym przedsięwzięciu będzie oznaczała rezygnację z jakiejkolwiek współpracy, niejako z założenia.

Istotą konfliktów jest rzeczywista sprzeczności interesów lub potencjalna sprzeczność interesów. Wśród obszarów pojawienia się takich sprzeczności można wymienić6:

- dostęp do zasobów i usług środowiska przyrodniczego,

- ograniczenia w poziomie emisji i imisji zanieczyszczeń,

- transgraniczne przemieszczanie się zanieczyszczeń,

- lokalizację obiektów niechcianych,

- awarie i katastrofy ekologiczne,

- odmienne oczekiwania odnośnie do rozwoju społeczno-gospodarczego,

- odmienne oczekiwania odnośnie do zagospodarowania przestrzennego,

6 J. F. Shogren, K. H. Balk, T. D. Croker, Environmental Conflicts and strategic Commitment, [w:] R. Petling, Cooperation and conflicts in Managing Environmental Resources, Springer 1992, podaję za: M. Burchard-Dziubińska, Konflikty ekologiczne zwiqzane z lokalizacja obiektów „niechcianych”, [w:] Konflikt i wspótpraca w realizacji strategii ekorozwoju, Wrocław 2003, s. 35-44. 
- odmienny stosunek do międzygeneracyjnej sprawiedliwość ekologicznej, która oznacza:

a) konieczność zachowania niepogorszonej (społecznie akceptowanej) jakości środowiska, w tym jego zasobów i użytków pozaekonomicznych, dla przyszłych generacji,

b) konieczność zabezpieczenia podstawowych surowców, a zwłaszcza nośników energii, dla potrzeb wzrostu gospodarczego w przyszłości

Pojawiające się na tym tle konflikty różnią się zasięgiem geograficznym (konflikty międzynarodowe, międzyregionalne, lokalne), charakterem wynikającym z przedmiotu konfliktu, liczbą, rodzajem i stopniem zaangażowania uczestników.

Wyborów dotyczących sposobu, skali i zakresu korzystania z zasobów i usług środowiska przyrodniczego dokonują ludzie występujący w roli konsumentów i producentów, to oni mogą tworzyć formalne lub nieformalne grupy społeczne w obszarze użytkowania i ochrony środowiska przyrodniczego. Zbieżność ich działań z zasadami zrównoważonego rozwoju zależy od tego, jak ludzie postrzegają relacje między rozwojem gospodarczym a użytkowaniem i ochroną środowiska, a mianowicie:

- jakie miejsce zajmuje gospodarka i środowisko przyrodnicze w systemie wartości?

- czy istnieje społeczne przyzwolenie na możliwość ograniczenia produkcji ze względów środowiskowych?

- czy społeczeństwo gotowe jest na zmianę stylu życia, poziomu i kierunków konsumpcji, wzorców zachowań na takie, które sprzyjałyby ochronie środowiska przyrodniczego?

- czy w społeczeństwie dostrzega się celowość finansowania działań prośrodowiskowych?

Przedstawione pytania z punktu widzenia nowej ekonomii instytucjonalnej są pytaniami dotyczącymi ukształtowanych w społeczeństwie instytucji nieformalnych oraz ich wpływu na działania poszczególnych osób, podmiotów gospodarczych i całych branż oraz grup społecznych.

7 B. Fiedor, Teoria trwatego rozwoju (ekorozwoju) jako krytyka neoklasycznej ekonomii środowiska i wzrostu gospodarczego, [w:] B. Fiedor, S. Czaja, A. Graczyk, Z. Jakubczyk, Podstawy ekonomii środowiska i zasobów naturalnych, Wyd. C. H. Beck, Warszawa 2002, s. 33. 


\section{MIEJSCE DZIAŁAŃ ZBIOROWYCH W REALIZACJI IDEI ZRÓWNOWAŻONEGO ROZWOJU}

Ochrona środowiska przyrodniczego i gospodarcze korzystanie z zasobów przyrodniczych są obszarami powstawania licznych konfliktów interesu wynikających z konkurencyjności celów jego użytkowników. Niektóre cele są wspólne dla wielu osób lub podmiotów gospodarczych. Wspólny interes jest przesłanką kształtowania się grup interesu i celem podejmowanych przez nie działań zbiorowych. W nowej ekonomii instytucjonalnej wskazuje się na istotną rolę działań zbiorowych podejmowanych przez grupy interesu, przede wszystkim z punktu widzenia ich wpływu na kształtowanie się instytucji. Działania te są uzupełnieniem niedoskonałego rynku i niedoskonałego regulatora, jakim jest państwo.

W niniejszym opracowaniu dla prezentacji grup interesu w kształtowaniu i ochronie środowiska przyrodniczego skorzystano z następujących koncepcji grup interesu:

- socjologicznej koncepcji grup interesu D. Trumana (zwanej pluralistyczną),

- ekonomicznej koncepcji grup interesu M. Olsona.

Według koncepcji D. Trumana, przedstawionej w pracy The Governmental Process, człowiek ma naturę społeczną, zatem powstawanie i istnienie grup w społeczeństwie jest zjawiskiem naturalnym. Jeżeli zatem pewne grupy ludzi wchodzą $\mathrm{w}$ interakcje, bo mają takie same lub podobne przekonania, poglądy, systemy wartości, reprezentują podobne postawy, będą zatem tworzyć grupy interesu dążące do osiągnięcia wspólnego celu preferowanego przez członków grupy ${ }^{8}$. Wspólnota zainteresowań może dotyczyć kilku obszarów, zatem ludzie mogą być członkami wielu różnych grup, których cele mogą być sprzeczne?

Postulat uwzględniania społecznych motywów zrzeszania się i tworzenia bodźców selektywnych oraz mechanizmów wyłączenia z grupy wniosły teorie powstałe na gruncie socjologii ekonomicznej. A. Sen zwracał uwagę na altruizm, który może być bardziej skuteczny niż interesowność w dążeniu do przetrwania na rynku. Podobne stanowisko zajmowali R. Hardin i J. Elster, który podkreślał znaczenie społecznej akceptacji dla działań zbiorowych. Problem ten dostrzegł również M. Olson, ale prezentował go w ramach tradycji kontraktu społecznego, gdzie mechanizm działania wyjaśniany jest przez tradycyjną ekonomię ${ }^{10}$.

\footnotetext{
D. Truman, The Governmental Process, New York 1958.

9 P. A. Sabatier, Przynależnośc do grup interesów a ich organizacja: przegląd teorii, [w:] J. Szczupaczyński (red.), Wtadza i spoteczeństwo, Wyd. Naukowe Scholar, Warszawa 1995.

10 B. Klimczak, Wybrane problemy i zastosowania ekonomii instytucjonalnej, Wyd. AE, Wrocław 2006, s. 58.
} 
Społeczna natura człowieka oznacza, że w sytuacji pojawiających się zagrożeń społecznych, np. związanych $z$ degradacją i ochroną środowiska przyrodniczego, grupy takie powstają spontanicznie. Osiąganie celów związanych z ochroną środowiska przyrodniczego prowadzi do uzyskania pewnego dobra publicznego - przynajmniej na poziomie deklaratywnym. Czasem podejmowane działania ukierunkowane są na realizację interesów własnych przywódców grupy, części lub wszystkich członków grup. Samoorganizacja może mieć formę zrzeszeń, organizacji społecznych, sieci organizacji, porozumień społeczności lokalnych, grup osób, koalicji itp.

Ekonomiczną koncepcję grup interesu przedstawił M. Olson, przede wszystkim w pracy The Logic of Collective Action. Koncepcja Olsona pozostaje w zgodzie z założeniami tradycyjnej ekonomii, iż każdy człowiek dąży do maksymalizacji swoich korzyści. Jednostki podejmują działania autonomiczne i mają na celu interes własny, ich wybory są racjonalne, a swobodę wyborów określają instytucje tworzone przez państwo. Olson wskazuje, że w wyniku działania grupy mogą być dostarczane dobra, z których mogą korzystać zarówno członkowie danej grupy, jak i całe społeczeństwa ${ }^{11}$.

Według Olsona celem działań zbiorowych grup interesu jest dostarczanie dobra grupowego, jednakże sukces zależy od wielu czynników, takich jak wielkość grupy i związanych z tym możliwości stosowania bodźców selektywnych, które mogą być bodźcami pozytywnymi (nagrody, wyróżnienia, pochwały itp.) lub bodźcami negatywnymi (wykluczenia, kary itp.). Zbiorowe dobro grupy jest dla tworzących grupę dobrem publicznym, a zatem niewyłącznym w użytkowaniu, co stwarza potencjalne możliwości działań typu ,jazda na gapę. Dla jednostek tworzących grupę bodźcem do pozostania w grupie i wspólnego działania mogą być możliwości korzystania $\mathrm{z}$,produktów ubocznych” dostarczanych przez grupę.

Co ważne $z$ punktu widzenia użytkowania i ochrony środowiska przyrodniczego, Olson, analizując bodźce selektywne, służące mobilizowaniu członków grupy do działania, zwrócił uwagę na bodźce społeczne, takie jak prestiż, szacunek, przyjaźn i status społeczny związany z uczestnictwem w grupie. Bodźce te mogą mieć charakter bodźców pozytywnych i negatywnych, np. dezaprobata, lekceważenie, wykluczenie z grupy. Uwzględnia także bodźce moralne, jak poczucie obowiązku, winy i utrata szacunku. Przy czym bodźce powiększają lub ograniczają użyteczność poszczególnych osób. Bodźce społeczne można zatem traktować podobnie jak bodźce pieniężne ${ }^{12}$.

11 M. Olson, The Logic of Collective Action. Public Goods and the Theory of Groups, Harvard University Press, Cambridge 1965.

12 B. Klimczak, op. cit., s. 58. 
Grupę interesu w sferze ochrony i użytkowania środowiska przyrodniczego tworzą jednostki, które podejmują wspólne działania na rzecz realizacji wspólnego interesu. Grupy te mają następujące cechy:

- celem działań zbiorowych grup interesu jest dostarczanie dobra grupowego, między innymi korzystnych dla członków grupy regulacji w zakresie ochrony i użytkowania środowiska przyrodniczego, zarówno na poziomie międzynarodowym, jak i krajowym czy lokalnym;

- reprezentują interesy członków grupy wobec innych grup oraz podejmują działania, które stanowią ich ochronę przed działaniami innych grup lub przed niekorzystnymi zdarzeniami społecznymi, ekonomicznymi czy prawnymi, np. nieekologiczne grupy biznesowe kontra proekologiczne grupy biznesowe lub/i ekologiczne organizacje i ruchy społeczne;

- pośredniczą w przekazywaniu postulatów członków grupy ośrodkom decyzyjnym oraz mogą wpływać na opinię publiczną, rząd i parlament, zatem mogą wpływać na kierunki rozwiązań regulacyjnych w obszarze gospodarczego korzystania $\mathrm{z}$ dóbr i usług środowiska przyrodniczego.

Użytkowników środowiska przyrodniczego, którzy są potencjalnymi uczestnikami działań zbiorowych $\mathrm{w}$ tym obszarze $\mathrm{z}$ punktu widzenia sposobu postrzegania środowiska przyrodniczego, można $\mathrm{z}$ grubsza podzielić $\mathrm{w}$ następujący sposób ${ }^{13}$ :

- podmioty gospodarcze, dla których korzystanie ze środowiska przyrodniczego jest istotnym czynnikiem warunkującym działalność gospodarczą oraz znaczącym składnikiem ich funkcji użyteczności;

- poszczególne osoby i grupy społeczne, dla których środowisko przyrodnicze jest wartością samą $\mathrm{w}$ sobie, zatem zainteresowane są jego ochroną i racjonalnym gospodarowaniem jego zasobami;

- poszczególne osoby i grupy osób wykorzystujące własną aktywność w ochronie środowiska jako środek do osiągnięcia innych celów, dla uzyskania indywidualnych korzyści materialnych, społecznych, politycznych (ewentualne regulacje są "produktem ubocznym”).

Ludzie, którzy podejmują wybory w sferze produkcji i konsumpcji dóbr, również te dotyczące użytkowania i ochrony środowiska przyrodniczego, wyznają odmienne idee, mają zróżnicowane poglądy filozoficzne, reprezentują zróżnicowane postawy etyczno-moralne, co wpływa na ich postawy i zachowania w stosunku do przyrody. Można zatem podzielić wszystkie zainteresowane grupy społeczne

\footnotetext{
13 I. Rumianowska, Grupy interesu i grupy nacisku w ochronie środowiska, [w:] B. Klimczak (red.), Ekonomia instytucjonalna w Polsce. Doświadczenia i przysztość, Wydawnictwo UE, Wrocław
} 2010. 
i podmioty gospodarcze na dwa zasadnicze typy: nieekologiczne grupy interesu branżowe grupy producentów, grupy biznesowe, organizacje producentów i firm handlowych, przedsiębiorstwa i grupy przedsiębiorstw, które przedkładają cele ekonomiczne (przede wszystkim - maksymalizację zysku) nad cele ekologiczne (środowisko przyrodnicze traktowane jest instrumentalnie); proekologiczne grupy interesu - organizacje i grupy społeczne chcące mieć wpływ na politykę ekologiczną państwa i kształtowanie przyjaznych środowisku przyrodniczemu postaw i zachowań społecznych ${ }^{14}$. Wachlarz grup społecznych, formalnych i nieformalnych, poczynając od „ekologicznych barbarzyńców”, a kończąc na zwolennikach przebudowy świata zgodnie z ideą ekologii głębokiej, przedstawia rys. 1, ujmujący grupy społeczne w użytkowaniu środowiska przyrodniczego zgodnie $\mathrm{z}$ kryterium aksjologiczno-normatywnym:

Grupy uznające nadrzędność celów ekonomiczno-społecznych, akceptujące ekologiczne ograniczenia administracyjno-prawne. Pragmatyczni praktycy gospodarczy i gospodarstwa domowe (antropocentryzm)

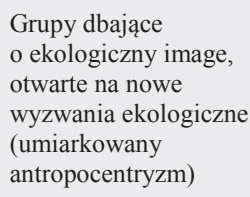

Grupy dbające o ekologiczny image, otwarte na nowe wyzwania ekologiczne (umiarkowany antropocentryzm)

"Umiarkowane" grupy ekologiczne uznające konieczność gospodarowania (umiarkowany przyrodocentryzm)

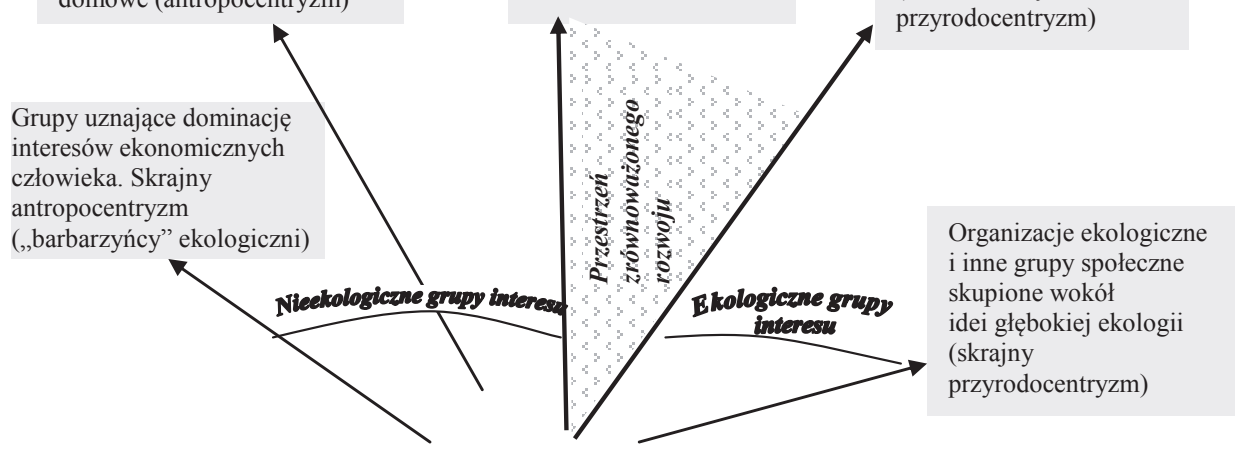

Stosunek do środowiska przyrodniczego i jego ochrony

Rysunek 1. Grupy społeczne w użytkowaniu i ochronie środowiska przyrodniczego w wymiarze aksjologiczno-normatywnym

Źródło: opracowanie własne oparte na stosowanym w literaturze podziale postaw społecznych wobec środowiska przyrodniczego w ujęciu aksjologiczno-normatywnym. Np. D. Kiełczewski, Ekologia społeczna, wydanie drugie zmienione, Wydawnictwo Ekonomia i Środowisko, Białystok 2001; S. Czaja, Etyczny wymiar ekologicznych aspektów gospodarowania (antropocentryzm versus przyrodocentryzm, [w:] B. Fiedor (red.), Podstawy ekonomii środowiska i zasobów naturalnych, Wydawnictwo C. H. Beck, Warszawa 2002. 
Wśród grup podejmujących wspólne działania w zakresie użytkowania i ochrony środowiska przyrodniczego możemy wyróżnić ${ }^{15}$ :

1. Nieekologiczne grupy interesu. Grupy biznesowe, dla których zakres i sposób korzystania z zasobów środowiska przyrodniczego jest warunkiem koniecznym prowadzenia działalności gospodarczej oraz istotnym czynnikiem decydującym o efektywności ekonomicznej, zatem upatrują one indywidualnych korzyści z określonych zmian instytucjonalnych, zwłaszcza regulacji. Wśród grup biznesowych można wyróżnić:

- Grupy ukierunkowane na osiąganie wąsko rozumianych korzyści ekonomicznych (maksymalizacji zysku), zatem cele pozaekologiczne maja charakter dominujący, środowisko przyrodnicze traktowane jest instrumentalnie, jako dostarczyciel zasobów przyrodniczych oraz usług w postaci przestrzeni pozwalającej na prowadzenie działalności gospodarczej, w tym również usług polegających na asymilacji odpadów i zanieczyszczeń. Powstające tu grupy interesów, np. branżowe grupy biznesowe czy koalicje producentów, działają w celu uzyskania większego i swobodniejszego dostępu do zasobów środowiska przyrodniczego;

- Branżowe grupy producentów, grupy biznesowe, organizacje producentów i firm handlowych akceptujące istniejące rozwiązania instytucjonalno-prawne w zakresie ochrony i użytkowania środowiska przyrodniczego, unikające wchodzenie w konflikty ekologiczne z innymi grupami społecznymi (legaliści). Celem nadrzędnym są cele ekonomiczne lub korzyści społeczno-ekonomiczne, natomiast ekologiczny interes grupy dotyczy zachowania istniejącego stanu rzeczy.

2. Biznesowe grupy interesu lokujące się $\mathrm{w}$ przestrzeni zrównoważonego rozwoju - branżowe grupy producentów, grupy biznesowe, organizacje producentów i firm handlowych, grupy przedsiębiorców zorientowanych proekologicznie. Grupy, które dążąc do osiągania korzyści ekonomiczno-społecznych, nie unikają wyzwań ekologicznych oraz podejmują działania i ponoszą koszty zmiany metod działalności gospodarczej na bardziej przyjazne środowisku przyrodniczemu. Dobrem wspólnym mogą być tu korzyści osiaggane z zaostrzenia regulacji $\mathrm{w}$ zakresie korzystania ze środowiska przyrodniczego, co mogłoby poprawić pozycję konkurencyjną członków grupy na rynku, np. przez wzrost prestizu społecznego i ukształtowanie image'u ekologicznego firmy oraz wzrost konkurencyjności cenowo-kosztowej firmy w przyszłości. Celowi temu mogą służyć również działania wspierające akcje organizacji ekologicznych dotyczące ochrony środowi-

15 Ibidem. 
ska przyrodniczego. Uzyskane dobro miałoby cechę niewykluczalności dla wszystkich podmiotów spełniających kryteria techniczno-technologiczne i ekologiczne.

We wszystkich wymienionych grupach istnieje duża możliwość ,jazdy na gapę". Czynnikami społecznymi ograniczającymi przynależność do grupy mogą być bodźce selektywne natury społecznej: negatywne, takie jak społeczne potępienie, negatywna ocena przez niektórych interesariuszy, lub pozytywne, na przykład akceptacja i wysoka ocena działań i przedsiębiorstwa, prestiż, zainteresowanie produktami oferowanymi na rynku itp.

3. Organizacje, grupy ekologiczne, ruchy ekologiczne, koalicje na rzecz osiągnięcia określonego celu środowiskowego. Mogą być klasyfikowane według najróżniejszych kryteriów: podstaw ideologicznych i filozoficznych, form organizacyjnych, składu społecznego grupy, charakteru i celów działań, stopnia zaangażowania w problematykę ekologiczną itp. ${ }^{16}$

Ze względu na programy i postulaty ekologiczne oraz radykalizm działań organizacje ekologiczne i grupy ekologiczne można podzielić na ${ }^{17}$ :

- pragmatyczne, które dążą do osiągania zakładanych celów przez wykorzystanie istniejących mechanizmów i możliwości. Występuje tu znaczne zróżnicowanie ze względu na cele i charakter oraz obszar prowadzonych działań, od organizacji ekologicznych i innych grup społecznych zainteresowanych całokształtem zagadnień związanych $\mathrm{z}$ ochroną środowiska przyrodniczego, poprzez te zainteresowane tylko ściśle określonymi problemami (np. realizacją lub wstrzymaniem realizacji konkretnego przedsięwzięcia) lub zainteresowane określonymi kierunkami rozwoju danej gałęzi gospodarki, np. energetyki (energetyka jądrowa, energetyka konwencjonalna, energia odnawialna), po grupy społeczne zainteresowane ochroną określonych elementów środowiska przyrodniczego lub ochroną przed określonymi rodzajami zagrożeń;

- organizacje i grupy konserwatorskie, które za główny cel uznają zachowanie naturalnej postaci przyrody, a w szczególności ochrony piękna krajobrazu, ginących gatunków roślin i zwierząt;

- organizacje i grupy ekologiczne zaliczane do ruchu „politycznej ekologii”, bardziej radykalne od wyżej wymienionych i o bardziej ogólnych celach działania. Najistotniejszym elementem ich działania jest dążenie do przebudowy społeczeństwa i jego struktury wartości.

16 Szerzej na ten temat zob. P. Gliński, Polscy Zieleni. Ruch spoteczny w okresie przemian, Wyd. IFiS PAN, Warszawa 1996.

17 H. Lisicka, Czy polskie organizacje ekologiczne petnia role grup nacisku, [w:] Z. Michalski, L. Rubisz (red.), Grupy interesu. Teorie i dziatania, Wyd. A. Marszałek, Toruń 2003, s. 310-314. 
Radykalnym programem i metodami działania wyróżniają się organizacje ekologiczne i grupy wyznające filozofię ekologii głębokiej. Inicjatywy tej grupy wiążą się, $\mathrm{z}$ jednej strony, $\mathrm{z}$ prowadzeniem kampanii przeciwko trucicielom środowiska, a $\mathrm{z}$ drugiej strony, $\mathrm{z}$ prowadzeniem edukacji ekologicznej oraz nauką bezpośredniego zaangażowania w ratowanie przyrody ${ }^{18}$.

\section{KIERUNKI DZIAŁAŃ ZBIOROWYCH W ZAKRESIE UŻYTKOWANIA I OCHRONY ŚRODOWISKA PRZYRODNICZEGO}

Celem działań zbiorowych środowisk gospodarczych są przeważnie korzystne regulacje prawno-administracyjne lub, rzadziej, ekonomiczno-rynkowe, dotyczące sposobu i skali korzystania danej branży lub sektora gospodarki z usług środowiska przyrodniczego i jego zasobów. Popyt na określone regulacje ekologiczne wynika $\mathrm{z}$ oczekiwania następujących korzyści: ograniczenia kosztów wynikających z gospodarczego użytkowania środowiska przyrodniczego i jego zasobów (powiększanie zysku); osiągania korzyści wynikających z ograniczenia wejścia do danej branży potencjalnych konkurentów; zagwarantowania swobody w ksztaltowaniu cen (przede wszystkim utrzymania ich na wyższym poziomie) lub ich kontroli; zagwarantowania ochrony przed konkurencją ze strony firm z krajów, gdzie regulacje ekologiczne są łagodniejsze i mniej restrykcyjne; uzyskania subsydiów lub ulg podatkowych; otrzymania koncesji lub przywilejów przetargowych; czasami uzyskania wyłączenia $z$ danej regulacji. Poszczególni producenci oraz grupy przedsiębiorstw, zgłaszając popyt na określone regulacje ekologiczne, dążą do osiągnięcia przewagi konkurencyjnej na rynku (obecnie lub w przyszłości) w wyniku innowacyjnych rozwiązań dostępnych tylko dla nich.

Jak zauważył M. Olson, wysoki stopień zorganizowania grup biznesowych oraz ich zdolność wywierania nacisku na organy władzy publicznej ma często związek z niewielką liczbą firm w danej branży (oligopolistycznymi strukturami wielu przemysłów) ${ }^{19}$. Powyższe spostrzeżenie znajduje swoje potwierdzenie w obserwowanych działaniach grup producentów, gdzie grupy interesu starają się uzyskać korzystne dla siebie regulacje przez zorganizowany lobbing, oferowanie usług w zakresie doradztwa i wiedzy eksperckiej, stabilność kontaktów z organami władzy wykonawczej, bezpośrednie kontakty z politykami, mobilność między sektorem publicznym a grupami interesu, wreszcie oferowanie korzyści materialnych.

\footnotetext{
18 D. Kiełczewski, Ekologia społeczna, wydanie drugie zmienione, Wyd. Ekonomia i Środowisko, Białystok 2001, s. 152-153.

19 M. Olson, op. cit., s. 143-148.
} 
Zadania ekologiczne o charakterze społecznym są realizowane, przede wszystkim, przez organizacje i grupy proekologiczne. Grupy zainteresowane ochroną środowiska i racjonalnym gospodarowaniem jego zasobami mogą dążyć do dostarczenia dobra publicznego w postaci regulacji ekologicznych, poprzez wywieranie nacisku na centrum decyzyjne lub na społeczeństwo. Znamiona bezpośredniego nacisku na centrum decyzyjne ma opiniowanie projektów ustaw i innych regulacji w zakresie ochrony i kształtowania środowiska przyrodniczego oraz działalność lobbingowa, współpraca $z$ agendami rządowymi, podejmowanie działań interwencyjnych, bezpośrednie działania, np. manifestacje, akcje protestacyjne, blokady, pikiety i inne spektakularne formy. Metody działań organizacji ekologicznych i grup wspierających często są niekonwencjonalne, czasami pozostają na granicy legalności, czego przykładem mogą być akty cywilnego nieposłuszeństwa.

Czasami organizacje ekologiczne lub nieformalne grupy społeczne, działające na rzecz ochrony środowiska przyrodniczego, potrafią skuteczniej, niż np. organizacje przemysłowe, zmobilizować swoich członków oraz skłonić ich do podjęcia określonych działań (nawet nielegalnych), aby w ten sposób wpływać na opinię publiczną i wywrzeć wpływ na decyzje władz, np. odnośnie do lokalizacji uciążliwej środowiskowo inwestycji (np. składowiska lub spalarni śmieci, oczyszczalni ścieków, budowy drogi, zapory wodnej, elektrowni jądrowej itp.). Często większą „siłę przetargową" mają grupy interesu działające w skali lokalnej. Ich naciski na władze samorządowe charakteryzują się relatywnie dużą skutecznością.

Zwykle wszystkie grupy interesu starają się najpierw bezpośrednio dotrzeć ze swoimi postulatami do odpowiednich decydentów, a gdy działania lobbingowe i bezpośrednie kontakty nie dają pozytywnych rezultatów, poszukują wsparcia mass mediów oraz mobilizują członków swojej grupy do udziału w protestach i akcjach informacyjno-perswazyjnych skierowanych do szerokich kręgów społecznych.

\section{ZAKOŃCZENIE}

W polityce ekologicznej państw wysokorozwiniętych dominującą formą regulacji dotyczących gospodarczego użytkowania środowiska przyrodniczego i jego zasobów są regulacje prawno-administracyjne, natomiast regulacje ekonomiczne są ich uzupełnieniem.

Dlatego też grupy nacisku powstające w sytuacjach konfliktów ekologicznych starają się, przez wywieranie nacisku na decydentów, wpływać na charakter i zakres instrumentów prawno-administracyjnych dotyczących gospodarczego użytkowania środowiska przyrodniczego i jego zasobów. Jeżeli konflikt dotyczy rywalizujących ze sobą grup producentów, wówczas zaangażowanie się poszcze- 
gólnych członków grupy, poziom zorganizowania się grupy oraz odpowiedni dobór metod i środków działania, a także odpowiednie ukierunkowanie działań mogą przesądzić o ostatecznym kształcie regulacji. W sytuacji, gdy stronami konfliktu są producenci i konsumenci, to regulacja jest zazwyczaj bardziej korzystna dla producentów, którzy tworzą skuteczniejsze grupy nacisku. Zapotrzebowanie na daną regulację może zostać zgłoszone przez organizacje konsumenckie, stowarzyszenia naukowe działające w sferze ochrony środowiska przyrodniczego, pozarządowe organizacje ekologiczne oraz ruchy społeczne o zasięgu krajowym, regionalnym czy lokalnym przeciwdziałające degradacji środowiska przyrodniczego. Są to przeważnie grupy duże, słabo zorganizowane, zatem ich skuteczność jest relatywnie mała. Mogą się jednak pojawić grupy nacisku, zwłaszcza lokalne, które będą skuteczne w swoich działaniach. Dotyczy to takich przedsięwzięć środowiskowych, w których korzyści dla poszczególnych członków są bardzo wysokie.

\section{BIBLIOGRAFIA}

Brundtland G. H., Our Common Future, Report of the World Commission on Environment and Development, Oxford University Press, Oxford 1987.

Fiedor B., Teoria trwatego rozwoju (ekorozwoju) jako krytyka neoklasycznej ekonomii środowiska i wzrostu gospodarczego, [w:] B. Fiedor, S. Czaja, A. Graczyk, Z. Jakubczyk, Podstawy ekonomii srodowiska i zasobów naturalnych, Wyd. C. H. Beck, Warszawa 2002.

Fiedor B., Dziatania zbiorowe w sferze zanieczyszczania środowiska i jego ochrony. Próba objaśnienia na podstawie teorii dóbr publicznych i teorii niedoskonatości rynku oraz teorii regulacji publicznej w gospodarce rynkowej, [w:] Dziatania zbiorowe - teoria i praktyka, PN AE we Wrocławiu, Wrocław 2003.

Gliński P., Polscy Zieleni. Ruch spoteczny w okresie przemian, Wyd. IFiS PAN, Warszawa 1996.

Graczyk A., Ekologiczne koszty zewnętrzne. Identyfikacja, szacowanie, internalizacja, Wyd. Ekonomia i Środowisko, Białystok 2005.

Kiełczewski D., Ekologia społeczna, wydanie drugie zmienione, Wyd. Ekonomia i Środowisko, Białystok 2001.

Klimczak B., Wybrane problemy $i$ zastosowania ekonomii instytucjonalnej, Wyd. AE, Wrocław 2006.

Lisicka H., Czy polskie organizacje ekologiczne petniq role grup nacisku, [w:] Z. Michalski, L. Rubisz (red.), Grupy interesu. Teorie i dziatania, Wyd. A. Marszałek, Toruń 2003.

North D., Institutions, institutional change and economic performance, Cambridge University Press, Cambridge 1990.

Olson M., The Logic of Collective Action. Public Goods and the Theory of Groups, Harvard University Press, Cambridge 1965.

Pawłowski A., Pawłowski L., Zrównoważony rozwój we wspótczesnej cywilizacji. Częśc 1: Środowisko a zrównoważony rozwój, „Problemy Ekorozwoju - Problems of sustainable development" 2008, vol. 3, no. 1. 
Pearce D., Turner R. K., Economics of Natural Resources and the Environment, New York 1990.

Priscoli J. D., Public Involvement, Conflict Management, Means to EQ and Social Objectives, "Journal of Water Resources Planning and Management" 1989, vol. 115, no. 1.

Rumianowska I., Grupy interesu i nacisku w ochronie środowiska przyrodniczego, [w:] B. Klimczak (red.), Ekonomia instytucjonalna w Polsce. Doświadczenia i przysztośc, Wydawnictwo UE, Wrocław 2010.

Sabatier P. A., Przynależnośc do grup interesów a ich organizacja: przeglad teorii, [w:] J. Szczupaczyński (red.), Wtadza i spoteczeństrwo, Wyd. Naukowe Scholar, Warszawa 1995.

Shogren J. F., Balk K. H., Croker T. D., Environmental Conflicts and strategic Commitment, [w:] R. Petling, Cooperation and conflicts in Managing Environmental Resources, Springer 1992, za: M. Burchard-Dziubińska, Konfikty ekologiczne zwiqzane z lokalizacja obiektów ,niechcianych", [w:] Konflikt i wspótpraca w realizacji strategii ekorozwoju, Wrocław 2003.

Truman D., The Governmental Process, New York 1958.

Woś A., Rozwój zrównoważony, „Zagadnienia Gospodarki Rolnej”1992, nr 1-3.

\section{STRESZCZENIE}

Ograniczoność zasobów i usług dostarczanych przez środowisko przyrodnicze, przy nieograniczonych oczekiwaniach społeczeństw w odniesieniu do konsumpcji, dóbr jest przesłanką konfliktów ekologicznych. Oznaczają one powstanie antagonistycznych stosunków w następstwie zaistnienia realnej lub potencjalnej sprzeczności interesów i priorytetów dotyczących użytkowania i ochrony środowiska przyrodniczego.

Realizacja koncepcji zrównoważonego rozwoju oznacza wprowadzanie zasad, norm i ograniczeń w gospodarczym użytkowaniu środowiska, zatem wpisuje się w przyczyny konfliktów wynikających ze sprzecznych oczekiwań i interesów poszczególnych podmiotów gospodarczych, grup społecznych, mieszkańców krajów, regionów świata w zakresie użytkowania zasobów i usług środowiska przyrodniczego.

W następstwie rzeczywistych lub potencjalnych konfliktów może dochodzić do współpracy przybierającej formę działań zbiorowych w relacjach człowiek-środowisko przyrodnicze-gospodarka. Celem działań zbiorowych grup interesu jest dostarczanie dobra wspólnego, między innymi korzystnych dla członków grupy regulacji, oraz ukształtowanie pożądanych preferencji, postaw i zachowań społecznych w zakresie ochrony i użytkowania środowiska przyrodniczego. 


\title{
ECOLOGICAL CONFLICTS AND COLLECTIVE ACTIONS IN THE AREA OF USING AND PROTECTING THE NATURAL ENVIRONMENT
}

\author{
SUMMARY
}

The scarcity of resources and services provided by the natural environment combined with the unlimited social expectations for the consumption of goods is the reason for ecological conflicts. They mean the emergence of antagonistic relations as a result of the occurrence of a real or a potential conflict of interests and priorities related to using and protecting the natural environment. Implementing the concept of sustainable development means the introduction of principles, standards and restrictions in the economic use of the natural environment. Therefore it forms part of the causes of conflicts in the use of environmental resources, arising from the contradictory expectations and interests of various firms, social groups, residents of countries or regions of the world. Such actual or potential conflicts may cause the cooperation which takes the form of collective action in the relationships "man-environment-economy." The goal of interest groups is to achieve the common good: favorable regulations and the formation of desired preferences, attitudes and social behavior relating to the protection and the use of the natural environment. 
